Original Research

\title{
Relationship Between the Application of a Full Day School System and Stress Levels in Junior High School
}

\section{Maulidiyah Junnatul Azizah Heru, Atika Jatimi, Fakhrun Nisa Fiddaroini, dan Achmad Syamsudin}

Faculty of Nursing, Universitas Airlangga, Surabaya, Indonesia

\begin{abstract}
Introduction: This research presents the relationship between the schools which implemented full day school and which did not apply the full day school to the level of stress students in junior high schools. This was influenced by the existence of regional autonomy as part of government policy and orientation toward quality education institutions.

Methods: This research used a quantitative correlational approach to obtain the significance of the relationship between the variables examined. The sampling technique used purposive sampling, with samples of 37 students for a group of cases and 37 students to control groups. Data analysis was conducted using the Kolmogorov Smirnov test.
\end{abstract}

Results: The results showed that in the case group there were 83.78 experiencing mild stress and 16.22 experiencing moderate stress, while in the control group there were 89.19 experiencing mild stress, and 10.81 experiencing moderate stress with P- value $0.000(<0.05)$.

Conclusion: The conclusion of this study is that more moderate stress levels are found in students who apply the Full Day School System in Junior High School.

\section{ARTICLE HISTORY}

Received: Dec 26, 2019

Accepted: Dec 31, 2019

\section{KEYWORDS}

stress levels; quality education institutions; full day school

\section{CONTACT}

Maulidiyah Junnatul Azizah Heru $\triangle$ maulidiyah.junnatul.azizah2018@fkp.unair.ac.id

$\fallingdotseq$ Faculty of Nursing, Universitas Airlangga, Surabaya, Indonesia

Cite this as: Heru, M. J. A., Jatimi, A., Fiddaroini, F.N.,\& Syamsudin, A. (2019). Relationship Between the Application of a Full Day School System and Stress Levels in Junior High School. Jurnal Ners, 14(3si), 374-377. doi:http://dx.doi.org/10.20473/in.v14i3(si).17217

\section{INTRODUCTION}

The full day school education system became popular in the 1980s in the United States and was followed by various other countries in Europe (Arifin, 2017). At present education in Indonesia has undergone several policy changes from time to time (Muali, Islam, El, \& Bali, 2018). One policy that had become a conversation and interesting to study was the policy on FDS (Full Day School) (Hakim \& Parameswari, 2015). In general, the education system in Indonesia is divided into two, namely the regular education system and the full day school education system, the fundamental difference between the two systems is the length of study time (Saudatul \& Baharun, 2018). Full day school can be interpreted as a school that applies a full day learning system or from morning to evening (Indra \& Haris, 2017).

In its implementation, a Full Day School based on a balancing program between cognitive, emotional, social, and spiritual abilities is considered an excellent program, because it makes student learning time effective and maximizes the full potential of students. Others think that Full Day School can make students overly-stressed due to the burden of learning. It can even cause children to experience physical and mental fatigue (Abai , M T M, Huda, A. Y S D, 2017).

In educational activities, students often experience stress because of their inability to adapt to the program at school. The stress experienced by students in the school environment will accumulate against psychological disorders and physical illness (Desmita, 2016). Stress that is often experienced by students is academic stress (Paulus W, T, \& W, 2014).

Based on the results of the Mufadhal Barseli study, it shows that in general the academic stress conditions of junior high school students in Padang are in the moderate category with a percentage of 41.1\%. This shows that students can control the situation or condition that causes stress, which is 
related to various academic demands. Although in general the students' academic stress conditions are in the moderate category, but some students are in the high academic stress category with a percentage of $28.8 \%$. This means that students do not escape the conditions of academic stress. High demands are placed on students both from parents, teachers and peers are one of the causes of the emergence of academic stress. Besides these things, there are $30.2 \%$ of students in low academic stress conditions. This proves that academic stress is not entirely negative meaning that it can be positive in the sense of a challenge to overcome it (Barseli, Ifdil, \& Nikmarijal, 2017).

The results of the interview with the Head of the Badridduja Junior School found that the Badridduja Middle School which from its inception in 2013/2014 had 21 students and had not implemented the Full Day School system, but after the Full Day School system was implemented there were several students who stopped and moved to other institutions. This happened because of the intense activities, heavy lessons, and a very high level of discipline that made students bored and could not stand the application of the Full Day School system.

\section{MATERIALS AND METHODS}

The design of this study was correlational with a case control approach. This study involved 74 respondents who were divided into two groups from two schools that were used as research sites. The schools published are Badriduja Junior High School and Al Mashduqiyah Junior High School. The study was conducted using a purposive sampling technique. The validity of the values obtained 0,243. Data collected was analyzed using kolmogorov smirnov.

\section{RESULTS}

Table 1 shows that respondents from a group of cases consisted of $26(70.27 \%)$ male students with 18 students in the control group (48.65\%). The age of the respondents from the case group is $12-14$ years old with 30 students or $81.08 \%$.

While the age of the control group 12-14 years of age accounted for 36 students or $97.3 \%$ table [2]. In this study the case group the majority of respondents from seventh grade numbered 29 students or $78.38 \%$. While from the control the majority also consisted from seventh grade totaling 29 students or 78.38 tables [3].

Based on the results of the Kolmogorov Smirnov test obtained a significant $(p$-Value $=0,000)$ and that value $(0,000<0.05)$. This value indicates that there is a relationship between the application of a full day school System and Stress Levels in Students junior high school at Badridduja Kraksaan-Probolinggo table [5]. After being analyzed using kolmogorov smirnovthen measuring the extent to which the strength of the two variables using the Lambda test obtained P-Value 0.756 and the value was greater than the approx.
Table 1 Distribution of Respondents in full day school and non-full day school

\begin{tabular}{lcccc}
\hline Characteristic & $\begin{array}{c}\text { Full } \\
\text { day } \\
\text { school } \\
\text { (n=37) }\end{array}$ & \% & $\begin{array}{c}\text { Non } \\
\text { Full } \\
\text { day } \\
\text { school } \\
\text { (n=37) }\end{array}$ & \% \\
\hline Sex & & & & \\
$\quad$ Male & 26 & $70.27 \%$ & 18 & $48.65 \%$ \\
$\quad$ Female & 11 & $29.73 \%$ & 19 & $51.35 \%$ \\
Age & & & & \\
$12-14$ & 30 & $81.08 \%$ & 36 & $97.3 \%$ \\
$15-17$ & 7 & $18.92 \%$ & 1 & $2.7 \%$ \\
Class & & & & \\
VII & 29 & $78.38 \%$ & 29 & $78.38 \%$ \\
VIII & 8 & $21.62 \%$ & 8 & $21.62 \%$ \\
& & & & \\
\hline
\end{tabular}

Table 2 Distribution of Stress Levels inStudents in two group

\begin{tabular}{ccccc}
\hline $\begin{array}{c}\text { Stress } \\
\text { Level }\end{array}$ & $\begin{array}{c}\text { Full } \\
\text { day } \\
\text { school } \\
\text { (n=37) }\end{array}$ & \% & $\begin{array}{c}\text { Non } \\
\text { Full } \\
\text { day } \\
\text { school } \\
\text { (n=37) }\end{array}$ & \\
\hline Low & 31 & $83.78 \%$ & 33 & $89.19 \%$ \\
Moderate & 6 & $16.22 \%$ & 4 & $10.81 \%$ \\
High & 0 & $0 \%$ & 0 & $0 \%$ \\
\hline
\end{tabular}

Table 3. Relationship Distribution between of a Full Day School System with Stress Levels to Students

\begin{tabular}{llll}
\hline $\begin{array}{l}\text { The } \\
\text { group }\end{array}$ & $\begin{array}{l}\text { Stress } \\
\text { Level }\end{array}$ & $\begin{array}{l}\text { Full Day } \\
\text { School }\end{array}$ & P- Value \\
\hline Case & Low & 31 & 0.000 \\
& Moderate & 6 & \\
& High & 0 & \\
Control & Low & 33 & \\
& Moderate & 4 & \\
& High & 0 & \\
\hline
\end{tabular}

Table 4 Overview of the Lambda Correlation Test

\begin{tabular}{llllll}
\hline $\begin{array}{l}\text { Stress } \\
\text { Level }\end{array}$ & $\begin{array}{l}\text { Full day } \\
\text { school } \\
\text { (n=37) }\end{array}$ & $\begin{array}{l}\text { Non full } \\
\text { day } \\
\text { school } \\
\text { (n=37) }\end{array}$ & & & \\
\hline Low & 31 & 33 & 0.756 & 0.000 \\
Moderate & 6 & 4 & & \\
High & 0 & 0 & & \\
\hline
\end{tabular}

value. sig. $0.000(0.756>0.000)$ and it can be concluded that the strength of the relationship between the independent variable and the dependent variable is interpreted strongly so that the correlation direction is positive $(+)$ table [6].

\section{DISCUSSION}

According to Astuti School with a full day school system was established to accommodate problems that exist in the community such as juvenile delinquency problems, parents of students expect their children to get a better religious education and avoid negative things, besides that full day school was established due to factors of work parents so they are 
not able to monitor the behavior of children after school (Astuti, 2013).

Full day school has a positive impact on student motivation in achievement so that it has a big influence on learning achievement (Subiantoro, Atmadja, \& Natajaya, 2013). Students who have a full day school system have better religious values and are able to develop and manage learning supported by educator guidance (Nurhayati, 2014).

This contrasts with the results of research that has been conducted that the Badridduja Junior High School students who apply the Full Day School system are found to experience mild stress as many as 31 students and moderate stress 6 people. While the results of research conducted on Al-Masduqiah Junior High School as a control group showed that 33 students had mild stress, moderate stress 4 students, and none of them experienced severe stress. While the results of research conducted on Al-Masduqiah junior high School as a control group showed that 33 students had mild stress, moderate stress 4 students, and none of them experienced severe stress.

The level of stress on Badriduja Junior High School students above occurs because the students experience boredom on average when the teacher explains the subject matter, many students complain when there are subjects that are not liked, students are also often angry because things are trivial when in class it makes it difficult for students to concentrate in participating in teaching and learning activities.

Mild stress levels usually occur in each individual and last for several minutes or hours and do not cause disease or disorders unless they occur continuously (Nurhayati, 2014). At this level of stress, individuals will feel calm when stress has ended. Furthermore, at moderate academic stress levels, individuals tend to be easily emotional and unfocused. This can disrupt academic activities (Australian Psychology Foundation, 2010).

Alvin stated that broadly academic stress is influenced by two factors namely internal factors and external factors. Internal factors are pressures originating from within a person which include mindset, personality, and beliefs while external factors are pressure originating from outside the student such as solid learning, pressure for higher achievement, encouragement of social status, and the influence of parents' pressure in better academic achievement (Sudarya.I.W, Bagia. I.W, 2014).

While those who oppose the application of FDS believe that fds causes students to become stressed because of the many learning burdens (Nurma Fitria, 2017). This full day school program does tend to make students feel bored, and stressed. There needs to be new innovations that can make students excited about living it. These innovations really need the teacher's role so that their students feel at home in school. Creating interesting and fun activities, so the Fullday school program continues (N L L Deck, 2017).

\section{CONCLUSION}

The conclusion was that students were applying the FDS System in Junior High School. Thereforenure $\mathrm{s}$ are expected to be used as an illustration for health services to prevent stress to students by providing health education / counseling on stressful factors and handling them and for educators are expended to avoid factors that can cause stress to students at school with new innovations at school.

\section{ACKNOWLEDGMENT}

We would like to say thank you very much for the respondents that really the cooperative research and headmaster of Badridduja junior high school and headmaster of Al-masduqiyah junior high school that supports this research is very well.

\section{REFERENCES}

Abai , M T M, Huda, A. Y S D, I. N. (2017). Strategy of Principals in Managing Conflict Responding to the Negative Impact of Implementing a Full Day School. Journal of Education: 2017 Theory, Research and Development, 2, 848-852.

Arifin, I. (2017). Manajemen Sistem Long Day School: Studi Etnografi pada SD Anak Saleh Kota Malang. 25-36.

Astuti, M. (2013). Implementation of Fullday School Program as an Effort to Encourage Social Development of Al-Ya'lu Superior Kindergarten Students in Malang City. Journal of Educational Policy and Development, 1, 133-140.

Australian Psychology Foundation. (2010). Anxiety Depression scale.

Barseli, M., Ifdil, I., \& Nikmarijal, N. (2017). Konsep Stres Akademik Siswa. 5(2005), 143-148.

Desmita. (2016). Psychology of Student Development. Bandung: Rosda.

Hakim, S. N., \& Parameswari, A. (2015). Comparative Study of Learning Achievement of Students in Full-Day Elementary School Class One Program obtained from Kindergarten Full-Day and Regular Programs. 363-367.

Indra, N. B., \& Haris, M. (2017). Social Sciences Student Learning Outcomes between Full Day School and not Full Day School. Progress in Social Sciences. Humanities Education and Research, 118:74.

Muali, C., Islam, S., El, M., \& Bali, I. (2018). Free Online Learning Based On Rich Internet Applications; The Experimentation of Critical Thinking About Student Learning Style Free Online Learning Based On Rich Internet Applications; The Experimentation of Critical Thinking About Student Learning Sty.

N L L Deck, I. U. R. (2017). Activity Innovation in Instilling Character Values in Elementary Schools That Implement Fullday School Programs. 2nd Annual Process, 188-194.

Nurhayati, I. (2014). Application of "Fun \& Full Day School" Learning System "to Increase Student 
Religiosity in SDIT Al Islam Kudus. Journal of Education and Learning Technology, 2, 231-244.

Nurma Fitria, R. (2017). Disiplin Siswa dalam Penerapan Full Day School. 61-75.

Paulus W, T, S., \& W, C. K. (2014). Maximizing Your Impact: Impacting Since Young Age. pt vision of grace Indonesia.

Saudatul, A., \& Baharun, H. (2018). Pendidikan Full Day School dalam Perspektif Epistemologi Muhammad 'Abid Al-Jabiri. POTENSIA J. Kependidikan Islam, 4(1), 1-22.
Subiantoro, R., Atmadja, N. B., \& Natajaya, N. (2013). All Day Learning Contribution, Learning Habits, Achieving Motivation Against Learning Achievement of Class IX Students of Albanna Junior High School Denpasar. Indonesian Education Administration Journal, 4.

Sudarya.I.W, Bagia. I.W, S. I. W. (2014). Analysis of Factors Affecting Stress in Students in Compiling Thesis. Examination Management Bisma E-Journal Genesha University, 2. 